Edinburgh. This institution was planned to give patients of moderate means the comforts, appliances, and conveniences which are provided gratuitously at hospitals for the poor. It contains 45 beds, and its development was made possible by the coöperation of the medical profession and the public. It is not run for profit and is intended to be self-supporting. It is arranged to admit cases paying at the rate of from $£ 11 s$. per week for board and nursing to $£ 33 s$., patients paying the latter fee only having a room to themselves. Previous experience of a similar home run on a small scale had justified the belief that such a home could be self-supporting, and it is gratifying to find that as a result of its first six months' working there is a very substantial balance on the right side.

The Queen Mary Home has already attracted considerable attention, having been visited by many medical men and others interested from other centres. The correctness of the principle underlying the establishment of this home may be regarded as established, and it is probable that, alike in the interests of the profession and of the public, an extension of such a scheme will be widely adopted in the future.

I am, Sir, yours faithfully,

Rdinburgh, Jan. 5th, 1914. Chalmers Watson.

\section{THE PHOSPHORUS CONTENT OF RICE.} To the Editor of THE LANCET.

SIR,-I am at present having to deal with an epidemic of beri-beri in the British regiment at this station. The disease, so far as can be found out, has not been described as occurring in the Sudan before.

In the course of investigations as to the possible cause attention has been paid amongst other things to the rice, though that is not regarded as the probable cause of the present outbreak, as rice is not a large constituent of the soldiers' food.

On referring to an article on the subject in your issue of July 26th, 1913, p. 236, an annotation on beri-beri in Siam and the work of Dr. H. Campbell Highet and others, I find the following statement: "The phosphorus content of a rice should not be less than 4 per cent., and this should be taken as the indicator of the safety or otherwise of the rice."

The figure mentioned is obviously a typographical error, and I should be much obliged if you would kindly inform me what the correct figure is.

Dr. Beam, research chemist at the Wellcome Tropical Research Laboratories, has kindly analysed for me the rice issued to the troops here, and his figure for phosphorus is $0^{\circ} 13$ per cent. This rice is the ordinary polished rice.

I am, Sir, yours faithfully,

$$
\begin{gathered}
\text { British Barracks, Khartoum (Sudan), } \\
\text { Dec. 27th, 1913. }
\end{gathered}
$$

* We regret very much to have overlooked the obvious misprint. The figure should have been, as Captain Stirling has correctly surmised, $0 \cdot 4$. - ED. L.

\section{THE ATROPINE TREATMENT OF SEA-SICKNESS. \\ To the Editor of The LaNCeT.}

SLR,-Apropos the advocacy of atropine in seasickness by Fischer, alluded to last week in an annotation in THE LANCET, I should like to say that I have found the hypodermic injection of sulphate of atropine to be the most reliable cure for sea-sickness I have ever tried. In 1906, when travelling for my health as surgeon in charge of a liner, I met an American physician who told me of this remedy, and I can strongly support Fischer's opinion as to its value. The milder cases do not often come under the notice of the surgeon, whose time is pretty fully occupied when in charge of from 1500 to 2000 people, and who has to act as surgeon, physician, bacteriologist, anæsthetist, and sometimes nurse. When called to a bad case of sea-sickness my plan was to give one-hundredth part of a grain of atropine sulphate hypodermically and repeat if necessary in an hour or two; often the sufferer would sleep a few hours, possibly because he had been without sleep for some time, and would then come up on deck and have no return of the sickness. I can endorse Fischer's opinion that relapses were not common and that one injection frequently cured.-I am, Sir, yours faithfully,

Reginald Pollard, M.B. Durh., D.P.H., \&c. South Kensington, Jan. 6th, 1914.

\section{INSTRUCTION IN THE NATURE OF ALCOHOLISM. \\ To the Editor of The LANCET.}

SIR,-May I ask you for space to endorse emphatically Dr. Hugh Wingfield's appeal for instruction for the rising generation of medical practitioners on the nature and proper treatment of alcoholism? It is essential that old and provedly erroneous theories as to cause and treatment of delirium still to be found in medical text-books should cease to be taught, and the more modern and proved theories taught in their place. If alcoholism and its rictims are to receive proper attention, which they are not getting at present, the nature of alcoholism must be understood, as at present it most emphatically is not, by the bulk of general practitioners. The differential diagnosis between dipsomania, pseudo-dipsomania, and chronic alcoholism must be understood and the treat. ment appropriate to each applied. Lastly, the profession must be taught, in order that they may in turn teach the laity, that this or that combination of drugs, while good so far as it goes in selected cases, or mere isolation from alcohol with or without drugs, while also of benefit so far as it goes, is not, without psychic treatment in its widest sense, sufficient or efficient treatment of alcoholism; and that imprisonment or the infliction of fines (the latter usually paid by long-suffering friends and relations) for drunkenness is as harmful as it is futile.-I am, Sir, yours faithfully,

J. W. AsTLeY Cooper, L.R.C.P. Edin., Medical Superintendent, Ghyllwoods Sana
Jan. 5th, 1914.

\section{THE NATIONAL INSURANCE ACT: THE SURPLUS FUND. \\ To the Editor of THE LANCET.}

SIR,-As the panel practitioners have evinced considerable interest since the publication of $\mathrm{my}$ letters to the press $r e$ the disposal of the so-called surplus fund, they would, I believe, like to learn whether $I$ have any further developments to announce.

1. Mr. Dawes, the chairman of the London Committee, writes to say that he has no authority to accept any legal notice on behalf of the Committee, but that all formal communications should be addressed to the clerk of the committee.

2. The chairman of the London Panel Practitioners' Committee writes as follows :-

I may say that our committee do agree that the doctors who accepted insured persons after April 15th should be 